\title{
Synthesis of iron-rich silicates under the $P$-T conditions of the lower mantle
}

\author{
Z. YANG ${ }^{1}$, L. ZHANG ${ }^{1 *}$ \\ ${ }^{1}$ Center for High Pressure Science and Technology \\ Advanced Research, 201203 Shanghai, China \\ (*correspondence: li.zhang@hpstar.ac.cn)
}

Iron-bearing bridgmanite $(\mathrm{Mg}, \mathrm{Fe}) \mathrm{SiO}_{3}$ is the most abundant mineral in the Earth's lower mantle. High pressure and high temperature experiments have been conducted to explore the thermal stability and phase relations in the $\mathrm{MgSiO}_{3}-\mathrm{FeSiO}_{3}$ system[1, 2, 3, 4]. However, there has long been a controversy about the existence of pure iron-silicate phase in the lower mantle. Here we employed a laser-heated diamond anvil cell (LH-DAC) to study the phase relations in the $\mathrm{FeO}-\mathrm{SiO}_{2}-$ and $\mathrm{MgO}-\mathrm{FeO}-\mathrm{SiO}_{2}-\mathrm{H}_{2} \mathrm{O}$ systems under the conditions of the lower mantle, and to understand the role of water in this system.

We have carried out some high pressure-temperature $(P-T)$ experiments between $40 \sim 95 \mathrm{GPa}, 2000 \sim 2500 \mathrm{~K}$. Under the conditions of $45 \mathrm{GPa}$ and $1900 \mathrm{~K}$ in the system $\mathrm{Fe}_{2} \mathrm{O}_{3}-\mathrm{SiO}_{2}-$ $\mathrm{H}_{2} \mathrm{O}$, we found almost all the hematite transferred into the high-pressure phase of magnetite ( $\mathrm{HP}-\mathrm{Fe}_{3} \mathrm{O}_{4}$, space group: Bbmm). With increasing P-T conditions to $95 \mathrm{GPa}$ and $2500 \mathrm{~K}$, only $\mathrm{FeO}$ was identified. In all runs, $\mathrm{SiO}_{2}$ existed as an individual phase, stishovite or $\mathrm{CaCl}_{2}$-type structure phase and we did not synthesize an iron-rich silicate yet. Future experiments will be carried out in the systems $\mathrm{FeO}-\mathrm{SiO}_{2}-\mathrm{H}_{2} \mathrm{O}$ and $\mathrm{MgO}-\mathrm{FeO}-\mathrm{SiO}_{2}-\mathrm{H}_{2} \mathrm{O}$ using laser-heated diamond anvil cells at $40 \sim 100 \mathrm{GPa}$ and $2000 \sim 3500 \mathrm{~K}$. The amount of $\mathrm{H}_{2} \mathrm{O}$ in the system can be controlled by using $\mathrm{SiO}_{2}$ gel containing 2 wt. $\% \mathrm{H}_{2} \mathrm{O}$. Water can produce an oxidized lower mantle region through redox reactions between water and iron/iron oxides, i.e., $4 \mathrm{FeO}+2 \mathrm{H}_{2} \mathrm{O}=\mathrm{FeH}+3 \mathrm{FeOOH}_{x}$ (py-phase) [5]. Through this study, we aim to synthesize pure iron-rich silicates under hydrous lower mantle conditions. The results will be of primary relevance for composition and dynamics of the lower mantle.

[1] Tange, Y. et al, (2009) J. Geophys. Res. 114, B02214. [2] Dorfman, S.M. et al, (2013) Earth Planet. Sci. Lett.361, 249257. [3] Zhang, L. et al, (2014) Science 344, 877-882. [4] T. Arimoto et al, (2019) Phys. Earth Planet. Inter. 295106297. [5] Ho-Kwang Mao, et al., (2017) Natl .Sci. Rev. 4: 870-878. 